\title{
Fat-soluble vitamin (A, D, E, and $\beta$-carotene) contents from a Portuguese autochthonous cow breed-Minhota
}

\author{
H. M. M. Ramalho, ${ }^{\star}$ J. Santos, ${ }^{\star}$ S. Casal, ${ }^{\star}$ M. R. Alves, ${ }^{\star} \dagger$ and M. B. P. P. Oliveira ${ }^{\star 1}$ \\ ${ }^{*}$ REQUIMTE/Dep. Ciências Químicas, Faculdade de Farmácia, Universidade do Porto, Rua de Jorge Viterbo Ferreira no. 228, \\ 4050-313 Porto, Portugal \\ †REQUIMTE/Escola Superior de Tecnologia e Gestão de Viana do Castelo, Av. do Atlântico, Apartado 574, 4900-348 Viana do Castelo, Portugal
}

\begin{abstract}
In Portugal, commercial milk is obtained almost entirely from cows of the Holstein breed. However, other breeds may also show dairy aptitude, and produce milk of good quality. The aim of this study was to investigate the effect of the breed factor in the vitamin contents of milks from Holstein and the autochthonous Portuguese breed Minhota, as well as possible variations due to season. Milk samples were collected from 15 cows of each breed. Milk from Minhota cows showed higher contents of retinol, retinyl palmitate, $\alpha$-tocopherol, and $\beta$-carotene. No differences were verified between breeds regarding vitamin $\mathrm{D}_{3}$ content, but Holstein cows presented higher amounts of provitamin $\mathrm{D}_{3}$. Seasonal variations were not observed for milk samples from Holsteins, and only a very small variation was observed for milk samples from Minhota cows, mainly in retinol, $\alpha$-tocopherol, and provitamin $\mathrm{D}_{3}$ levels. This study revealed that breed has a pronounced effect on milk fat-soluble vitamins, which is an important observation regarding future genetic selection plans. Also, the increased vitamin amounts found in milk from Minhota cows can be regarded as an important nutritional parameter that can potentiate the economical value of this breed.
\end{abstract}

Key words: milk, fat-soluble vitamin, breed effect, seasonal variation

\section{INTRODUCTION}

Vitamins are defined as a group of complex organic micronutrients present in food and in nutritional supplements required for normal metabolism and function. Fat-soluble vitamins are essential for human health and play important roles in body functions, such as in vision (vitamin A), calcium absorption (vitamin D), and antioxidant protection in cell membranes (vitamin E; Mor-

Received October 31, 2010.

Accepted May 8, 2012.

${ }^{1}$ Corresponding author: beatoliv@ff.up.pt rissey and Hill, 2009). Several studies have highlighted the very important role of vitamins as antioxidants and their ability to prevent chronic diseases, especially those believed to have an oxidative stress component such as cardiovascular diseases and cancer (Lopes et al., 2003). The inadequate vitamin intake can cause metabolism disorders, both in humans and animals, with vitamins $\mathrm{A}$ and $\mathrm{D}$ being highly correlated with deficiency syndromes.

Milk has been recognized as an important element in human diets because it provides a large variety of essential nutrients, such as lipids, proteins, AA, vitamins, and minerals, which are all required for the normal growth and development of mammals. Humans are a special case among mammals because after being deprived of their mother's milk, they keep on consuming milk and dairy products from other species, mainly from cows, buffaloes, goats, and sheep.

The consumption of milk and dairy products is often faced as a prerequisite for a well-balanced diet due to their beneficial health effects, especially with respect to the high biological values of milk proteins and vitamin contents. Vitamin A is the most abundant, but vitamins $\mathrm{E}, \mathrm{D}$, and $\beta$-carotene are also present (Haug et al., 2007). Vitamin A occurs mainly as a mixture of retinyl FA esters and free retinol, with total amounts ranging from 10 to $100 \mu \mathrm{g} / 100 \mathrm{~mL}$. These amounts are complemented by provitamin A carotenoids, mainly $\beta$-carotene, with reported levels varying between 3 and $50 \mu \mathrm{g} / 100 \mathrm{~mL}$ (Morrissey and Hill, 2009). The major vitamer of vitamin $\mathrm{E}$ in milk is $\alpha$-tocopherol, ranging from 20 to $70 \mu \mathrm{g} / 100 \mathrm{~mL}$. Concerning vitamin $\mathrm{D}$, both vitamin $\mathrm{D}_{3}$ (cholecalciferol) and provitamin $\mathrm{D}_{3}$ (7-dehydrocholestrol) can be present in the low-nanogram-per100-mL level (Morrissey and Hill, 2009). Although, in absolute terms, milk cannot be regarded as an important source of vitamin D, the volume of milk ingested, as recommended by several health authorities, will provide a substantial part of the recommended vitamin D intake. Therefore, this fact justifies the evaluation of vitamin D in milk. In Denmark, a study by Jakobsen and Saxholt (2009) showed that milk products contribute 
$10 \%$ of the total dietary intake of vitamin D. Hulshof et al. (2006) stated that in the Netherlands, milk and dairy products represent a 15 to $20 \%$ contribution of total vitamin A intake, depending on the age group. However, it is also known that milk composition can be affected by internal (breed) and external factors (season, nutrition, stage of lactation, and milking system; Lindmark-Månsson et al., 2003; Ellis et al., 2007).

The dairy sector in the European Union has major economic importance at several levels. The consumption of milk and dairy products has increased sharply in the past years. Holstein-Friesian is the principal cow breed used to produce milk worldwide, due to its efficiency and high production rates, and Portugal is not an exception. However, some autochthonous Portuguese breeds represent high economic and cultural value for local populations. Among these autochthonous Portuguese breeds, Minhota is one of the most important, and its origin can be traced back to the northwest of Portugal, in a region called Minho (Figure 1), an important agricultural area, with livestock being one of the main activities in the region. The Minhota breed is, today, mainly used for high-quality meat production. However, it also has an important historical background in milk production, mostly used in dairy products of recognized quality. The Association of Minhota breeders (APACRA), created in 1996, is implementing programs to promote the commercial value of the milk from Minhota as part of a biodiversity strategy program, also taking into consideration strategies for the sustainability of small producer activities. Therefore, it is important to characterize the nutritional potential of milk from Minhota cows to advertise its quality attributes, especially regarding its bioactive components, such as vitamins. This information will be crucial for dairy local industries, which may see an opportunity when using this milk as a raw material, favoring farmer activities and consumer health.

Milk composition has been studied by many groups over decades. Some work has focused on the discrimination among breeds, taking into account different chemical components, such as FA, protein, and vitamin contents (Beeson, 1935; Krukovsky et al., 1950; Thompson et al., 1964; Lawless et al., 1999; Hulshof et al., 2006; Talpur et al., 2006). External factors that can influence the levels of vitamins $\mathrm{A}$ and $\mathrm{E}$ and $\beta$-carotene in milk have been another issue of interest in several studies. Among these factors, lactation stage (Jensen et al., 1999; Calderón et al., 2007), season (Thompson et al., 1964; O'Brien et al., 1999; Lindmark-Månsson et al., 2003; Hulshof et al., 2006; Ellis et al., 2007), and feeding system (Havemose et al., 2004; Nozière et al., 2006; Ellis et al., 2007) have been evaluated. Although several reports on milk composition in Europe exist, no detailed reports on the milk from Minhota cows exist, an important aspect of the programs designed to promote the economic value of this breed. Vitamin D content in milk is one aspect that most of the abovementioned studies do not report, with vitamins $\mathrm{A}$ and $\mathrm{E}$ and $\beta$-carotene being the only fat-soluble vitamins usually monitored.

Therefore, the main objective of this work was to fill in the gap of information regarding the important autochthonous Minhota breed, through a comparative study of the contents of vitamins A, D, E, and $\beta$-carotene between the milks from Minhota and Holstein-Friesian cows, raised in the same region (Minho) and subject to the same feeding practices.

\section{MATERIALS AND METHODS}

\section{Milk Samples}

The Holstein-Friesian $(\mathrm{n}=15)$ and Minhota $(\mathrm{n}=15)$ dairy cows used in this study were raised on several private farms located in northern Portugal (Figure 1). The farms were selected among those that could guarantee a minimal influence of external factors on milk composition, mainly geographical areas, feeding strategies, and hygienic conditions. According to the producers, the cows selected for this study were subjected to a similar diet: during most of the year they grazed in natural pastures, except in the winter months, when the diet was supplemented with corn silage, hay, and some corn flour. Milk samples from individual cows were collected once per month, between October 2008 and September 2009, occasionally with some missing samples. By the

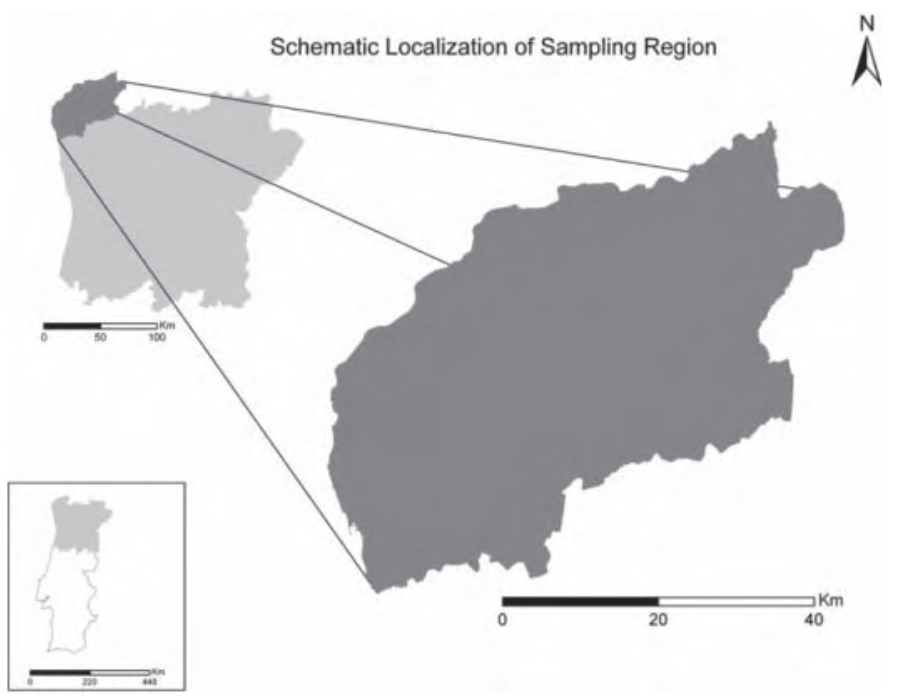

Figure 1. Schematic localization of sampling region in northern Portugal included in this study of milk. 
end of this project, a total of 104 milk samples from Minhota cows and 140 from Holstein-Friesian cows were collected and studied. All samples were carefully transported to the laboratory, under refrigeration, and stored at $-25^{\circ} \mathrm{C}$ until analysis.

\section{Reagents and Standards}

Retinol, retinyl acetate, retinyl palmitate, cholecalciferol (vitamin $\mathrm{D}_{3}$ ), 7-dehydrocholesterol (provitamin $\mathrm{D}_{3}$ ), DL- $\alpha$-tocopherol, and $\beta$-carotene were from SigmaAldrich (St. Louis, MO). Individual standard stock solutions were prepared in methanol or hexane ( $\beta$-carotene), ranging from 1.0 to $10.0 \mathrm{mg} / \mathrm{mL}$, flushed with nitrogen, and stored in amber vials at $-20^{\circ} \mathrm{C}$. Concentrations were regularly evaluated by UV measurements, according to their specific absorption coefficients in different solvents. Further dilutions were performed as required for calibration purposes. The internal standard tocol [2-methyl-2-(4,8,12-trimethyltridecyl)chroman-6-ol] was obtained from Matreya Inc. (Pleasant Gap, PA) and $\beta$-apo-8'-carotenal was purchased from Fluka (Spain). The internal standards solution, containing both tocol and $\beta$-apo- $8^{\prime}$-carotenal, was prepared in methanol, and stored at $-20^{\circ} \mathrm{C}$ in an amber glass vial.

High performance liquid chromatography-grade acetonitrile, dichloromethane, and methanol were obtained from Merck KGaA (Darmstadt, Germany). Ethyl acetate was from Sigma-Aldrich (Steinheim, Germany). Butylated hydroxytoluene (BHT) was obtained from Sigma-Aldrich (Madrid, Spain) and a $0.1 \%$ ethanolic solution was prepared daily. Water was purified with a Seral system (Seralpur Pro $90 \mathrm{CN}$; Seral Erich Alhauser GmbH, Ransbach-Baumbach, Germany). Triethylamine was obtained from Alfa Aesar GmbH \& Co. KG (Karlsruhe, Germany). All other reagents were of analytical grade.

\section{Analytical Procedure}

Vitamin contents were determined by HPLC. A liquid-liquid extraction method followed by reverse-phase HPLC separation and quantification was validated by a series of assays. The determination of limit of detection, limit of quantification, linearity range, intra- and interday precision, and accuracy of the method was assessed. The limit of detection ranged from 0.1 to 4.0 $\mathrm{ng} /$ injection and the limit of quantification ranged from 0.4 to $11.2 \mathrm{ng} /$ injection. The HPLC analysis showed high reproducibility for all vitamins, with coefficients of variation ranging from $1 \%$ in intraday to $13 \%$ in interday evaluations. Chromatographic resolution was adequate, showing excellent relative standard deviation
(\%) for retention times and peak areas. The extraction method was adjusted to minimize the solvent consumption and the recovery assays showed complete recoveries (97-109\%) for the compounds analyzed. In addition to the characteristics referred, the method used followed a simple and rapid protocol and provided reliable results. Aliquots of milk $(3.0 \mathrm{~mL})$ were transferred into $15-\mathrm{mL}$ amber glass vials. Proteins were precipitated by addition of ethanol with $0.1 \% \mathrm{wt} / \mathrm{vol}$ of BHT $(3 \mathrm{~mL})$, in the presence of internal standards $(100 \mu \mathrm{L})$. Vials were capped and mechanically homogenized (30 s) by vortexing, followed by $2 \mathrm{~min}$ in an ultrasonic bath for fat micelles disruption. Then, $3 \mathrm{~mL}$ of $\mathrm{n}$-hexane was added, and the mixture was vigorously shaken (vortexing for $1 \mathrm{~min})$ and centrifuged (5 min at 2,370 $\times g$; Heraeus Sepatech GmbH, Osterode, Germany). The organic phase was transferred to a second amber glass tube, and the process was repeated once more with $3 \mathrm{~mL}$ of n-hexane. The organic phases were combined, washed twice with $2 \mathrm{~mL}$ of ethanol/water (1:1, vol/vol), taken to dryness under a nitrogen stream, resuspended with $200 \mu \mathrm{L}$ of dichloromethane/methanol (2:1, vol/vol), and injected into the HPLC system.

\section{HPLC Equipment}

Chromatographic analysis was performed on a HPLC integrated system (Jasco Corp., Tokyo, Japan), equipped with 2 Jasco PU-980 pumps, an AS-2057 Plus automated injector (refrigerated), and an MD2015 Plus multiwavelength diode-array detector (DAD) connected in series to an FP-920 fluorescence detector (Jasco Corp.), programmed for excitation at $290 \mathrm{~nm}$ and emission at $330 \mathrm{~nm}$ (gain 10).

Chromatographic separation of the compounds was achieved with a reversed-phase C18 $(3 \mu \mathrm{m}, 25-\mathrm{cm} \times$ 4.6-mm i.d.) from Phenomenex Inc. (Torrance, CA), and a Phenomenex C18 (4 $\mu \mathrm{m}, 10 \times 3.9$-mm i.d.) security guard column, operating at constant temperature $\left(24^{\circ} \mathrm{C}\right)$. The mobile phase selected was A (acetonitrilewater-triethylamine, 95.5:4:0.5, vol $/ \mathrm{vol} / \mathrm{vol})$ and $\mathrm{B}$ (ethyl acetate) in gradients (0-6 min, $25 \% \mathrm{~B} ; 6-7 \mathrm{~min}$, linear gradient from 25 to $30 \% \mathrm{~B} ; 7-13 \mathrm{~min}, 30 \% \mathrm{~B}$; 13-15 min, linear gradient from 30 to $70 \%$ B; $15-18$ min, $70 \% \mathrm{~B} ; 18-21 \mathrm{~min}$, linear gradient from 70 to $25 \%$ B; followed by 4 min with $25 \%$ B for reconditioning and stabilization). The flow rate was $1.0 \mathrm{~mL} / \mathrm{min}$ and the injection volume was $20 \mu \mathrm{L}$. Vitamin $\mathrm{E}$ was quantified using fluorescence signals, with tocol as internal standard. Retinoids (retinol, retinyl acetate, and retinyl palmitate) were monitored at $325 \mathrm{~nm}$, vitamin $\mathrm{D}_{3}$ at $264 \mathrm{~nm}$, provitamin $\mathrm{D}_{3}$ at $280 \mathrm{~nm}$, and $\beta$-carotene at $450 \mathrm{~nm}$, all quantified against $\beta$-apo- $8^{\prime}$-carotenal (450 

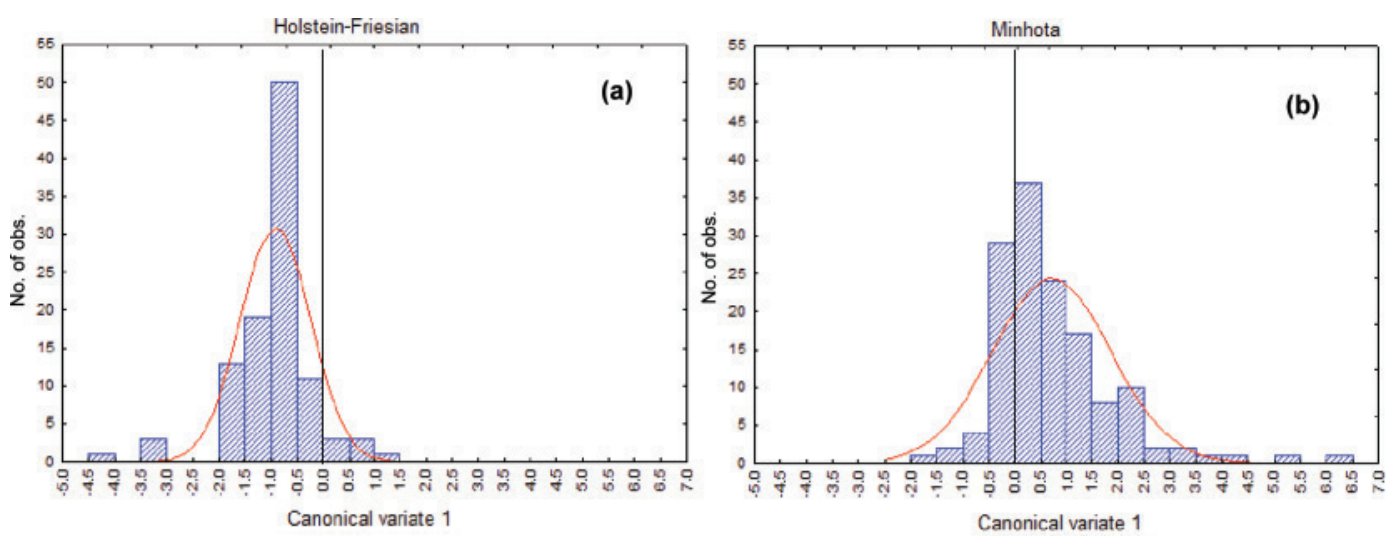

Figure 2. Canonical variates analysis evaluating differences between breeds (Holstein-Friesian vs. Minhota): plots of canonical variate (root) (1 per breed); obs. = observations. Color version available in the online PDF.

$\mathrm{nm})$. Sample peaks were identified by comparing both retention time and spectra with those of standard reference compounds.

\section{Statistical Analysis}

Results were submitted to univariate and multivariate analyses to assess possible differences between the milks from the 2 breeds (Minhota vs. Holstein-Friesian), and also to determine seasonal variations within breeds. Multivariate ANOVA and discriminant analyses were used to evaluate between-group differences, and were complemented by canonical variates analysis (CVA) to enable visualization of the observed differences. Besides general initial characterizations, whenever multivariate statistics pointed to consistent differences, ANOVA and Tukey post hoc tests (usually confirmed by the nonparametric Mann-Whitney tests) were carried out for all vitamins to elucidate and validate conclusions from multivariate approaches. All analyses were supported by the Statistica for Windows statistical package (StatSoft Inc., Tulsa, OK) following standard methodologies (e.g., Mardia et al., 1979).

\section{RESULTS AND DISCUSSION}

\section{Breed Influence on Milk Vitamin Composition}

To analyze the results obtained in this work, a first multivariate approach was carried out to determine if significant differences existed between milk from Minhota and Holstein-Friesian breeds, with all fat-soluble vitamin contents being taken into consideration simultaneously. Discriminant analysis, followed by canonical variate analysis were carried out, to determine and simultaneously visualize those differences. Discriminant analysis, with a Wilks' lambda of 0.5994 [approximate
$F(6.237)=26.39885, P<0.0000]$, showed that significant differences exist but will not be very evident. Canonical variate analysis generates only 1 canonical dimension due to the definition of only 2 groups (Holstein/Minhota). As can be seen in Figure 2, Holstein samples are displaced toward the negative (left) part of canonical variate 1 , whereas Minhota samples are displaced toward the positive (right) side of the canonical axis. The normal curves in the graphs show that departures from normality were small in both groups and could be neglected for the purpose of our studies.

Following the conclusions about the normality of the data distribution referred to in the previous paragraph and shown in Figure 2, a univariate study was carried out to evaluate the importance of each vitamin. Table 1 reports the fat-soluble vitamin contents determined in raw milk from the 2 cow breeds (Minhota and HolsteinFriesian). The results are presented as mean values, standard deviation, and minimum and maximum contents, whereas $P$-values represent the difference among breeds and seasonal variations. In accordance with other studies described in the literature, in this paper, the results are also expressed in micrograms per grams of fat.

This is the first report on milk vitamins from the Minhota breed. As previously mentioned, breed is an internal factor expected to have an influence on milk composition. Another important factor reported as affecting the nutritional value of milk is the seasonal variation. Therefore, both factors were analyzed in this work to assess their influence on vitamin composition.

In cow's milk, vitamin A is present as free retinol, retinol esters, and carotene (provitamin A; Öste et al., 1997), in different ratios. Most reports evaluate total vitamin A content after hydrolysis, limiting the information that can be obtained from the evaluation of the proportion of each natural vitamin form. The exclu- 
Table 1. Vitamin content ( $\mu \mathrm{g} / \mathrm{g}$ of fat) of milk from the Minhota and Holstein-Friesian breeds

\begin{tabular}{|c|c|c|c|c|c|c|c|c|c|}
\hline Vitamin & \multicolumn{4}{|c|}{ Minhota } & \multicolumn{4}{|c|}{ Holstein-Friesian } & $P$-value \\
\hline Retinol & 0.22 & 0.15 & 0.03 & 0.88 & 0.13 & 0.08 & 0.02 & 0.46 & $* * *$ \\
\hline Total vitamin A & 9.98 & 4.70 & 1.88 & 30.79 & 8.39 & 5.45 & 0.71 & 48.71 & $*$ \\
\hline$\alpha$-Tocopherol & 32.79 & 19.46 & 4.24 & 132.75 & 15.52 & 6.68 & 3.50 & 33.23 & $* * *$ \\
\hline Vitamin $\mathrm{D}_{3}$ & 0.11 & 0.07 & 0.01 & 0.35 & 0.10 & 0.07 & 0.01 & 0.37 & NS \\
\hline
\end{tabular}

$* P<0.05 ;{ }^{* * *} P<0.001$.

sion of the hydrolysis step from the extraction method enables the distinction between retinol and its esters present in the samples analyzed.

Regarding milk vitamin contents from the 2 breeds, vitamin A was present in all samples, as free retinol and retinyl palmitate. Mean values found in the milk of Minhota cows were $0.22 \pm 0.15 \mu \mathrm{g} / \mathrm{g}$ of fat and 17.89 $\pm 8.54 \mu \mathrm{g} / \mathrm{g}$ of fat for retinol and retinyl palmitate, respectively. In milk from Holstein-Friesian cows, the values obtained were significantly lower $(0.13 \pm 0.08$ $\mu \mathrm{g} / \mathrm{g}$ of fat for retinol and $15.12 \pm 9.93 \mu \mathrm{g} / \mathrm{g}$ of fat for retinyl palmitate; Table 1). Retinyl acetate is a synthetic form of vitamin A used for food fortification, and was not found in any sample, as expected for raw milk. The values obtained for free retinol and retinyl palmitate are in accordance with Gomis et al. (2000), one of the few authors that applied an analytical methodology without hydrolysis.

Regarding the total content of vitamin A without $\beta$-carotene, the results were similar to those found in different countries, as in Swedish milk by LindmarkMånsson et al. (2003), in Dutch milk by Hulshof et al. (2006), in Danish milk by Jensen et al. (1999), and in French milk by Calderón et al. (2007). However, Ellis et al. (2007) reported lower values in samples from the United Kingdom. Pires et al. (2003) is the only publication that evaluates milk vitamin contents from an autochthonous Portuguese cow breed: Barrosã. These authors reported that milk from Barrosã cows has higher levels of vitamin A than that of HolsteinFriesian cows, agreeing with our results and confirming the added value of the milk from autochthonous breeds.

$\beta$-Carotene is a secondary source of vitamin A, considered a precursor, and is usually present in milk. Values for $\beta$-carotene (mean $\pm \mathrm{SD}$ ) were $3.60 \pm 2.13$ $\mu \mathrm{g} / \mathrm{g}$ of fat and $1.45 \pm 1.15 \mu \mathrm{g} / \mathrm{g}$ of fat, for milks from Minhota and Holstein cows, respectively, again with high statistical significance $(P<0.001$; Table 1$)$. Jensen et al. (1999) and Hulshof et al. (2006) reported slightly higher $\beta$-carotene contents, and the values obtained by Calderón et al. (2007) were also 3- to 4-fold higher than the results obtained in the current study. In general terms, the results obtained in the current study for total vitamin A in milk from Holstein-Friesian cows showed similar results to earlier studies, but values for $\beta$-carotene were slightly lower. According to Nozière et al. (2006), in their review about carotenoids in milk, it is normal to expect considerable variation for these compounds among breeds, with higher variations to be expected for $\beta$-carotene than for total vitamin A.

Concerns $\alpha$-tocopherol content, mean values were $32.79 \pm 19.46 \mu \mathrm{g} / \mathrm{g}$ of fat and $15.52 \pm 6.68 \mu \mathrm{g} / \mathrm{g}$ of fat for Minhota and Holstein milk, respectively. Milk from Minhota cows presented a significantly larger $(P$ $<0.001$ ) amount of this compound. Although most of the literature describes vitamin $\mathrm{A}$ as the major fatsoluble vitamin present in milk, our results showed that vitamin $\mathrm{E}$ was present in large amounts. Ellis et al. (2007) in the United Kingdom and Jensen et al. (1999) in Denmark obtained similar results and presented similar conclusions. Chauveau-Duriot et al. (2010) also described the presence of $\gamma$-tocopherol in milk samples using an ultra performance liquid chromatography (UPLC) system. This vitamer was not detected in our samples, which is probably due to feeding composition and not to analytical methods. The values obtained in this research were within the range reported in the literature (Krukovsky et al., 1950; Jensen et al., 1999; Lindmark-Månsson et al., 2003; Calderón et al., 2007; Ellis et al., 2007; Butler et al., 2008). Vitamin E contents varied significantly between milk from Minhota and Holstein cows, being approximately 3 times higher in the former. This fact could be related to Minhota cow metabolism and its greater secretory capacity for $\alpha$-tocopherol, as reported earlier by Jensen et al. (1999). Those authors found differences in secretory capacity of $\alpha$-tocopherol and $\beta$-carotene in Holstein cows from different sires. Therefore, as vitamin $\mathrm{E}$ is considered an important natural antioxidant, the highest amounts in the milk from Minhota cows are important, as they increase protection against oxidative lipid damage and, consequently, increase the shelf-life of milk. 
Table 2. Discriminant analysis considering Holstein and Minhota breeds and 4 seasons ${ }^{1,2}$

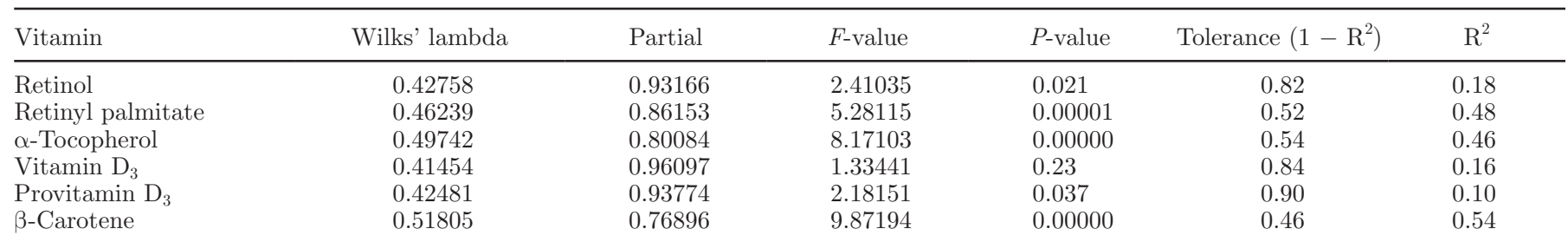

${ }^{1}$ Summary: number of variables in model $=6$; grouping $=$ breed/season; Wilks' lambda $=0.39836$ approximate $F(42.1082)=5.5867, P<$ $0.0000]$.

${ }^{2}$ The values of tolerance and $\mathrm{R}^{2}$ measure the relative contribution of each vitamin to explain differences between groups, when the contribution of all other vitamins has already been considered in the model.

The study of vitamin $\mathrm{D}_{3}$ and provitamin $\mathrm{D}_{3}$ was also included in this work. In terms of mean $( \pm \mathrm{SD})$ contents, milk from Minhota cows contained $0.11 \pm 0.07 \mu \mathrm{g}$ of vitamin $\mathrm{D}_{3} / \mathrm{g}$ of fat and $0.46 \pm 0.39 \mu \mathrm{g}$ of provitamin $\mathrm{D}_{3} / \mathrm{g}$ of fat. Holstein-Friesian cow milk had similar $(P$ $>0.05)$ vitamin $\mathrm{D}_{3}$ and higher $(P<0.05)$ provitamin $\mathrm{D}_{3}$ values (on the order of $0.10 \pm 0.07$ and $0.77 \pm 0.69$ $\mu \mathrm{g} / \mathrm{g}$ of fat, respectively). As reported above, a limited number of studies on the evaluation of vitamin $\mathrm{D}_{3}$ and provitamin $\mathrm{D}_{3}$ in raw milk are available. The results obtained in the current work are in accordance with the values for both vitamins reported by Adachi and Kobayashi (1979) and Gomis et al. (2000), who worked with processed milk, whereas Lindmark-Månsson et al. (2003) found lower values. Pires et al. (2003), in raw milk from Barrosã cows, found higher values of vitamin D. The higher levels of vitamin $\mathrm{D}_{3}$ found in the current work in comparison with other references, may result from differences among breeds and feeding practices, but it must also be taken into consideration that different analytical methodologies may lead to different conclusions. No significant differences in vitamin $\mathrm{D}_{3}$ levels were observed between milk from the 2 breeds in the current work. In the case of provitamin $\mathrm{D}_{3}$, milk samples from Holstein cows showed higher values $(P>$ 0.05) than samples from Minhota cows.

Looking at the overall content of all milk components evaluated, milk from Minhota cows had higher levels of almost all of the compounds, which enables us to infer that these differences could imply an advantage in nutritional value of this milk.

\section{Influence of Seasonal Variation on the Vitamin Composition of Milk}

To evaluate possible differences observed in different seasons, discriminant analysis was carried out with 8 groups: Holstein and Minhota cows and, within each breed, the seasons autumn, winter, spring, and summer. Again, a Wilk's lambda value of 0.39836 [approximate $F(42.1082)=5.5867, P<0.0000]$, shows that differences existed between groups, when all parameters were considered simultaneously, but some of the differences were difficult to observe. Although not very evident (see Table 2), vitamin $\mathrm{D}_{3}$ was not important for discrimination, and $\alpha$-tocopherol and $\beta$-carotene were found to be the most discriminant parameters (with the lowest $P$-values).
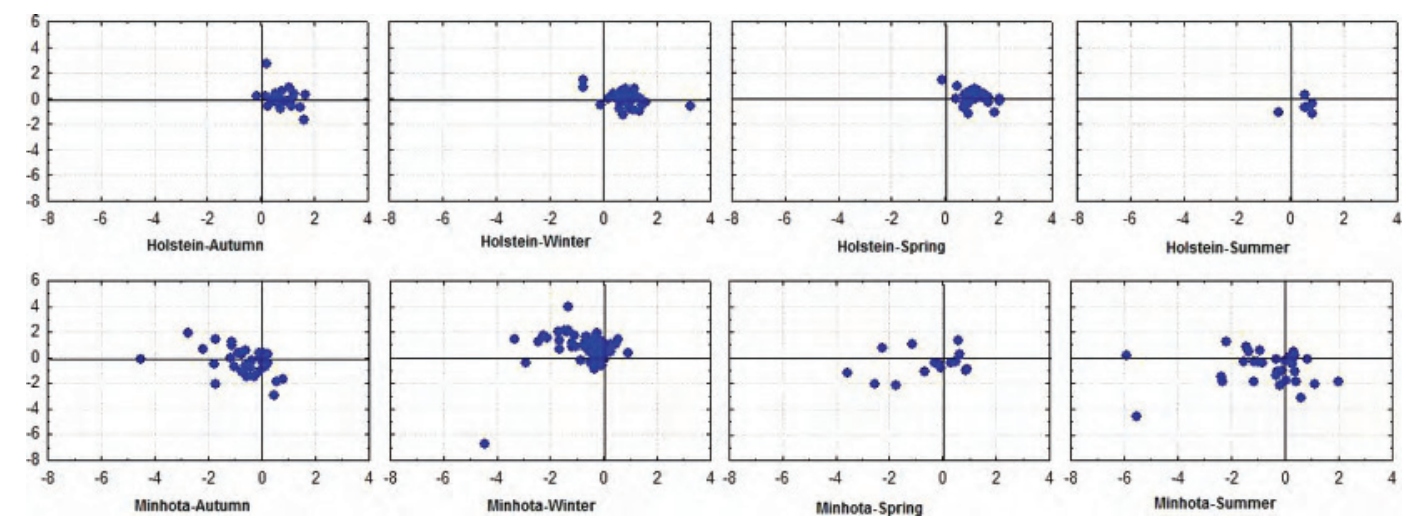

Figure 3. Scatterplot of milk samples from Holstein-Friesian and Minhota breeds according to season. Color version available in the online PDF. 
Table 3. Pooled within-group correlations between vitamins and canonical variates (CVAR; roots) comparing breeds/seasons

\begin{tabular}{lccrrrr}
\hline Vitamin & CVAR 1 & CVAR 2 & CVAR 3 & CVAR 4 & CVAR 5 & CVAR 6 \\
\hline Retinol & -0.4302 & -0.3051 & -0.1707 & -0.7322 & 0.3956 & 0.0131 \\
Retinyl palmitate & -0.2043 & -0.2523 & -0.6908 & -0.0409 & -0.1318 & -0.6312 \\
Q-Tocopherol & -0.7482 & -0.5530 & -0.0264 & 0.1343 & -0.0910 & -0.3276 \\
Vitamin $\mathrm{D}_{3}$ & -0.0584 & -0.1720 & 0.1823 & -0.0035 & 0.6697 & -0.6966 \\
Provitamin $\mathrm{D}_{3}$ & 0.2068 & -0.2631 & 0.2393 & -0.4998 & -0.5962 & -0.4749 \\
$\beta_{\text {-Carotene }}$ & -0.7756 & 0.2249 & -0.2926 & -0.0667 & -0.1385 & -0.4885 \\
Eigenvalue & 0.6300 & 0.2679 & 0.1052 & 0.0642 & 0.0284 & 0.0043 \\
Cumulative $(\%)$ & 57.28 & 81.63 & 91.20 & 97.03 & 99.61 & 100.00 \\
\hline
\end{tabular}

Under these circumstances, a canonical variate analysis will show differences, but will be not easy to interpret. Figure 3 shows the results and Table 3 shows the interpretation of canonical dimensions. All eigenvalues were below 1 , showing that within-group variations overcame between-group variations. It can be seen that $\alpha$-tocopherol and $\beta$-carotene were highly correlated with the negative part of canonical variate 1 , which contained around $60 \%$ of the total information. Figure 3 shows that the Minhota groups are mainly displaced toward the left of the graph, showing, again, the importance of these 2 vitamins for discrimination (higher in Minhota cows). Remaining dimensions were difficult to interpret and may just have been dependent on a few extreme values.

In these graphics (Figure 3), it becomes evident that Holstein samples were quite stable throughout the seasons, always lying in the same position in relation to the canonical dimensions, whereas Minhota samples showed some variation. Data for Holstein cows seemed to have a more homogenous distribution than those for the Minhota breed, which seemed to be distributed without clear organization. This wide variation observed in milk from individual cows in all compounds analyzed in milk from Minhota cows is in agreement with other studies published that also found high coefficients of variation in retinol and $\beta$-carotene from milk of individual cows (Thompson et al., 1964; Nozière et al., 2006; Swensson and Lindmark-Mansson, 2007). The variation found in this work could be due to the differences between individual cows, suggesting genetic variability in this breed.

Carrying out a new analysis with solely Minhota samples (Table 4), discriminant analysis showed similar results [i.e., although significant, the discrimination obtained was low, with a Wilks' lambda of 0.573203 (approximate $F=3.836438, P=0.00000$ )]. With the 4 Minhota groups, 3 canonical variates were developed. Canonical variate 1 represents a correlation between all vitamins, all loaded in its negative part, except for $\beta$-carotene, loaded in the positive side, in agreement with previous results. The only difference is the fact that retinol, correlated with the positive side of canonical variate 2 , seems to be high in several samples, especially in the majority of Minhota spring samples. A displacement winter/autumn/spring/summer seems to be present (from low in $\beta$-carotene and high in the other vitamins, to low in other vitamins and high in $\beta$-carotene).

To complement previous analyses, a multivariate ANOVA was carried out, which yielded a Wilks' lambda equal to 0.0629 , confirming significant differences in vitamin contents among seasons $(P=0.000)$. To determine more accurately which vitamins varied and in which seasons, ANOVA analyses for each vitamin were done and all turned out to be significant. Consequently, the variation in each vitamin level for each pair of seasons was assessed using multiple comparison tests (Tukey post hoc tests) and the results (only the significant ones) are shown in Table 5. Retinol and reti-

Table 4. Analyses of variance evaluating significance of differences of individual vitamins throughout the year in relation to the milk of Minhota cows

\begin{tabular}{|c|c|c|c|c|c|c|c|c|}
\hline Vitamin & SS effect & df effect & MS effect & SS error & df error & MS error & $F$-value & $P$-value \\
\hline Retinol & 0.4412 & 3 & 0.1471 & 1.814 & 136 & 0.01334 & 11.02298 & 0.000002 \\
\hline Retinyl palmitate & 309.1718 & 3 & 103.0573 & $3,024.747$ & 136 & 22.24079 & 4.63371 & 0.0041 \\
\hline Total vitamin $\mathrm{A}$ & 103.5263 & 3 & 34.5088 & 932.403 & 136 & 6.85591 & 5.03344 & 0.0024 \\
\hline$\alpha$-Tocopherol & 30.8746 & 3 & 10.2915 & 354.388 & 136 & 2.60579 & 3.94948 & 0.0097 \\
\hline Vitamin $\mathrm{D}_{3}$ & 0.4644 & 3 & 0.1548 & 5.670 & 136 & 0.04169 & 3.71250 & 0.013 \\
\hline Provitamin $\mathrm{D}_{3}$ & 489.6376 & 3 & 163.2125 & $3,359.969$ & 136 & 24.70565 & 6.60628 & 0.00034 \\
\hline$\beta$-Carotene & 6.5109 & 3 & 2.1703 & 379.532 & 136 & 2.79068 & 0.77769 & 0.51 \\
\hline
\end{tabular}


Table 5. Tukey post hoc tests evaluating the significance of differences of individual vitamins for any pair of seasons, in relation to the milk of Minhota cows (only significant differences are shown)

\begin{tabular}{|c|c|c|c|c|c|c|}
\hline \multirow[b]{2}{*}{ First/second season } & \multicolumn{2}{|c|}{ Sample size } & \multirow[b]{2}{*}{ Vitamin } & \multicolumn{2}{|c|}{ Mean value $(\mu \mathrm{g} / \mathrm{g}$ of fat $)$} & \multirow[b]{2}{*}{$P$-value } \\
\hline & First season & Second season & & First season & Second season & \\
\hline Autumn/spring & 35 & 16 & Provitamin $\mathrm{D}_{3}$ & 4.675 & 10.714 & 0.0003 \\
\hline \multirow[t]{2}{*}{ Winter/spring } & 56 & 16 & Retinol & 0.202 & 0.369 & 0.0000 \\
\hline & 56 & 16 & Retinol palmitate & 10.388 & 15.314 & 0.0013 \\
\hline \multirow[t]{2}{*}{ Spring/summer } & 16 & 33 & Retinol & 0.369 & 0.254 & 0.0061 \\
\hline & 16 & 33 & Vitamin $\mathrm{D}_{3}$ & 0.546 & 0.379 & 0.037 \\
\hline
\end{tabular}

nol palmitate seemed to have a peak in spring, whereas vitamin $\mathrm{D}_{3}$ and provitamin $\mathrm{D}_{3}$ seemed to be higher in colder seasons. $\alpha$-Tocopherol tended to increase in warmer seasons. As a general conclusion, it can be said that although significant differences $(P<0.05)$ between seasons in the vitamin contents of milk from Minhota cows were detected, the high individual variation registered in our data did not allow clear modeling of a seasonal variation that other authors have described (Ellis et al., 2007; Butler et al., 2008).

\section{CONCLUSIONS}

The results obtained in this work highlight the differences between milk from Minhota and Holstein-Friesian breeds, and show the potential of the former to be used with advantage for milk production. Due to significant superiority in almost all fat-soluble vitamin contents, and taking into account the high nutritional value presented by the milk from Minhota cows, this could represent an improved balance of nutrients for human diets. The results in this work support the findings of earlier studies about vitamin contents in milk from different breeds, suggesting the possibility of obtaining milk products with improved nutritional quality by choosing the correct breed. Considerable variations within breed may be found, as was observed in the current work in relation to the milk from the Portuguese autochthonous breed. The high within-breed variations observed suggest the existence of genetic variability that need to be considered in these types of studies. Also, seasonal variations must not be neglected. These findings are also very important, as they may provide important contributions to biodiversity preservation. Adding value to autochthonous breeds will promote the well-being of local, depressed communities with an increase in income. These advantages, or positive effects, will also avoid extinction of autochthonous breeds as has been observed with the Minhota breed since 2002, according to the European Community (Araújo, 2003).

\section{ACKNOWLEDGMENTS}

H. Ramalho is grateful to Alban Office for a $\mathrm{PhD}$ grant (E07D401312BR). J. Santos is thankful to Fundação para a Ciência e Tecnologia (Lisbon, Portugal) for the $\mathrm{PhD}$ grant $\mathrm{SFRH} / \mathrm{BD} / 66476 /$ financed by Programa Operacional do Potencial Humano-Quadro de Referência Estratégico Nacional (POPH-QREN, Lisbon, Portugal) and subsidized by ESF and MCTES. The authors thank Associação Portuguesa dos Criadores de Bovinos de Raça Minhota (APACRA, Ponte de Lima, Portugal), and Associação para o Apoio à Bovinicultura Leiteira do Norte (ABLN, Vila do Conde, Portugal) for providing milk samples. This work was supported by Fundação para a Ciência e Tecnologia through project no. PEst-C/EQB/LA0006/2011.

\section{REFERENCES}

Adachi, A., and T. Kobayashi. 1979. Identification of vitamin $\mathrm{D}_{3}$ and 7-dehydrocholesterol in cow's milk by gas chromatography-mass spectrometry and their quantitation by high-performance liquid chromatography. J. Nutr. Sci. Vitaminol. (Tokyo) 25:67-78.

Araújo, J. P. P. 2003. Caracterización etnológica, genética y productiva de la raza bovina Minhota. PhD Thesis. Universidad de Santiago de Compostela, Santiago de Compostela, Spain.

Beeson, W. M. 1935. Influence of breed and ration on the carotene and vitamin A content of milk. J. Anim. Sci. 1935:54-56.

Butler, G., J. H. Nielsen, T. Slots, C. Seal, M. D. Eyre, R. Sanderson, and C. Leifert. 2008. Fatty acid and fat-soluble antioxidant concentrations in milk from high- and low-input conventional and organic systems: Seasonal variation. J. Sci. Food Agric. 88:1431-1441.

Calderón, F., B. Chauveau-Duriot, B. Graulet, M. Doreau, and P. Nozière. 2007. Variation in carotenoids, vitamin A and E, and color in cow's plasma and milk during late pregnancy and the first three months of lactation. J. Dairy Sci. 90:2335-2346.

Chauveau-Duriot, B., M. Doreau, P. Nozière, and B. Graulet. 2010. Simultaneous quantification of carotenoids, retinol, and tocopherol in forages, bovine plasma, and milk: Validation of a novel UPLC method. Anal. Bioanal. Chem. 397:777-790.

Ellis, K. A., A. Monteiro, G. T. Innocent, D. Grove-White, P. Cripps, W. G. McLean, C. H. Howard, and M. Mihm. 2007. Investigation of the vitamins $\mathrm{A}$ and $\mathrm{E}$ and $\beta$-carotene content in milk from UK organic and conventional dairy farms. J. Dairy Res. 74:484-491.

Gomis, D. B., M. P. Fernández, and M. D. Gutiérrez Alvarez. 2000. Simultaneous determination of fat-soluble vitamins and provitamins 
in milk by microcolumn liquid chromatography. J. Chromatogr. A 891:109-114.

Haug, A., A. T. Høstmark, and O. M. Harstad. 2007. Bovine milk in human nutrition-A review. Lipids Health Dis. 6:25-40.

Havemose, M. S., M. R. Weisbjerg, W. L. P. Bredie, and J. H. Nielsen. 2004. Influence of feeding different types of roughage on the oxidative stability of milk. Int. Dairy J. 14:563-570.

Hulshof, P. J. M., T. van Roekel-Jansen, P. van de Bovenkamp, and C. E. West. 2006. Variation in retinol and carotenoid content of milk and milk products in the Netherlands. J. Food Compost. Anal. 19:67-75.

Jakobsen, J., and E. Saxholt. 2009. Vitamin D metabolites in bovine milk and butter. J. Food Compost. Anal. 22:472-478.

Jensen, S. K., A. K. B. Johannsen, and J. E. Hermansen. 1999 Quantitative secretion and maximal secretion capacity of retinol, $\beta$-carotene and $\alpha$-tocopherol into cow's milk. J. Dairy Res. 66:511-522.

Krukovsky, V. N., F. Whiting, and J. K. Loosli. 1950. Tocopherol, carotenoid and vitamin A content of the milk fat and the resistance of milk to the development of oxidized flavors as influenced by breed and season. J. Dairy Sci. 33:791-796.

Lawless, F., C. Stanton, P. L'Escop, R. Devery, P. Dillon, and J. J. Murphy. 1999. Influence of breed on bovine milk cis-9, trans11-conjugated linoleic acid content. Livest. Prod. Sci. 62:43-49.

Lindmark-Månsson, H., R. Fondén, and H.-E. Pettersson. 2003. Composition of Swedish dairy milk. Int. Dairy J. 13:409-425.

Lopes, C., S. Casal, B. Oliveira, and H. Barros. 2003. Retinol, betacarotene, and alpha-tocopherol in heart disease. Pages 118-136 in Nutrition and Heart Disease: Causation and Prevention. R. R. Watson and V. R. Preedy, ed. CRC Press, Boca Raton, FL.

Mardia, K. V., J. V. Kent, and J. M. Bibby. 1979. Principal component analysis. Pages 213-254 in Multivariate Analysis. Academic Press, London, UK.
Morrissey, P. A., and T. R. Hill. 2009. Fat-soluble vitamins and vitamin $\mathrm{C}$ in milk and milk products. Pages 527-572 in Advanced dairy chemistry: Lactose, water, salts and minor constituents. Vol. 3. 3rd ed. P. F. Fox and P. H. L. McSweeney, ed. Springer, New York, NY

Nozière, P., B. Graulet, A. Lucas, B. Martin, P. Grolier, and M. Doreau. 2006. Carotenoids for ruminants: From forages to dairy products. Anim. Feed Sci. Technol. 131:418-450.

O'Brien, B., T. Lennartsson, R. Mehra, T. M. Cogan, J. F. Connolly, P. A. Morrissey, and D. Harrington. 1999. Seasonal variation in the composition of Irish manufacturing and retail milk. 3. Vitamins. Irish J. Agric. Food Res. 38:75-85.

Öste, R., M. Jägerstad, and I. Andersson. 1997. Vitamins in milk and milk products. Pages 347-402 in Advanced Dairy Chemistry. P. F Fox, ed. Chapman \& Hall, New York, NY.

Pires, P., É. Fernandes, M. Vilarinho, M. Barros, R. Ferreira, L. Carneiro, G. Almeida, and M. V. Vaz-Velho. 2003. Comparison of milk from two different cow breeds Barrosã and Frísia. Electron. J. Environ. Agric. Food Chem. 2:514-518.

Swensson, C. and H. Lindmark-Mansson. 2007. The prospect of obtain beneficial mineral and vitamin contents in cow's milk through feed. J. Anim. Feed Sci. 16(Suppl. 1):21-41.

Talpur, F. N., M. I. Bhanger, and M. Y. Khuhawar. 2006. Comparison of fatty acids and cholesterol content in the milk of Pakistani cow breeds. J. Food Compost. Anal. 19:698-703.

Thompson, S. Y., K. M. Henry, and S. K. Kon. 1964. Factors affecting the concentration of vitamins in milk: I. Effect of breed, season and geographical location on fat-soluble vitamins. J. Dairy Res. $31: 1-25$ 